\title{
JEKK

\section{Mixed Methods Systematic Review : Kejadian Cabin Fever Selama Pembatasan Sosial Saat Penyebaran Penyakit Sars, Mers Dan Covid-19}

\author{
Michelle Christo*, Lintang Dian Saraswati*, Ari Udiyono *, Dwi Sutiningsih* \\ * Bagian Epidemiologi dan Penyakit Tropik, Fakultas Kesehatan Masyarakat \\ Universitas Diponegoro, Semarang, Indonesia
}

\begin{abstract}
Background: SARS, MERS and Covid-19 are the most dangerous viruses among the Human Coronavirus $(\mathrm{HCoV})$. The spreading of those diseases could cause cabin fever due to social restrictions as the control and prevention efforts. This study aims to map the impact of cabin fever during $\mathrm{HCoV}$ pandemic by the characteristic population and its causing factors.

Methods: A mixed method systematic review was conducted in five databases and its keywords were determined using MeSH (Medical Subject Headings). All articles were assessed after passed the last process (included). There are 11 articles included and 3 of them rated as strong quality. The findings were grouped into themes related to population characteristics and causative factors.

Result: The result shows among 4 themes of population characteristic, college student shows more than five symptoms of cabin fever. Out of all the causing factors, quarantine and social distancing shows more than five symptoms of cabin fever.

Conclusion: This review proves that cabin fever can occurs during the outbreak, epidemics and pandemics so, psychological treatment in the communities is needed during the spreading of the viruses. The treatment must be right because the symptoms of cabin fever differ according to population and the causes.
\end{abstract}

Keywords : Cabin Fever; Psychological Impact; Human Coronavirus; Systematic Review.

\footnotetext{
*Penulis korepondensi, michellenifinluri@gmail.com
} 


\section{Pendahuluan}

SARS-CoV, MERS-CoV dan Covid-19 merupakan jenis Human Coronavirus (HCoV) yang dapat menyebabkan penyakit pernafasan akut, dapat menyerang lintas spesies dan paling cepat menular antar manusia. ${ }^{1}$ Hal ini menyebabkan ketiga virus tersebut menjadi yang paling berbahaya diantara semua virus HCoV. Menurut data WHO, SARS memiliki 8.096 kasus dan 744 kematian; per Januari 2020 kasus MERS sebanyak 2.519 dan 866 kematian; serta pada akhir tahun 2020 sudah 79,2 juta orang positif Covid-19 dan 1,7 juta kematian (CFR 2,1\%) yang masih terus bertambah hingga kini. ${ }^{2-4}$ Karena cara penularan SARS, MERS dan Covid-19 (melalui udara, droplet dan kontak fisik) maka, upaya pengendalian penyakit yang paling tepat yaitu dengan melakukan pembatasan sosial. ${ }^{5}$

Pembatasan sosial seperti Self-isolation (isolasi mandiri), Self-quarantine (karantina mandiri), Physical distancing (menjaga jarak fisik) dan Community containment (penahanan komunitas) sangat efektif menekan penularan penyakit, namun penerapannya yang ketat dalam jangka panjang meningkatkan risiko terjadinya ganguan psikologis seperti perasaan terkurung dan terisolasi. ${ }^{6,7}$ Kebijakan pelaksanaan pembatasan sosial ditentukan berdasarkan nilai Reproduction Number (RO) dan kurva epidemiologi di masing-masing wilayah terdampak. Petro et al. mengungkapakn $R O$ SARS sebesar 1,7 - 1,9, MERS masih RO>1 sedangkan Covid-19 sebesar 2,0-2,5. ${ }^{8}$ Penelitian terbaru dari Liu et al. bahkan menujukkan $R O$ Covid-19 mencapai 3,28 setelah melewati pertengahan tahun 2020. ${ }^{9}$ Angka ini menunjukkan penularan virus yang masih terus belanjut dan belum diketahui kapan akan berakhir (khususnya pada MERS dan Covid-19). Situasi seperti ini memiliki peluang yang besar terjadinya perasaan terkurung dan terisolasi yang bekepanjangan.

Perasaan terkurung atau terisolasi ini disebut cabin fever. Cabin fever adalah kombinasi dari beberapa gejala yang timbul akibat kurungan, cuaca buruk, kejenuhan rutinitas, isolasi, merawat orang yang sakit dan kekurangan stimulasi. ${ }^{10}$ Kumpulan gejala yang dominan timbul yaitu tidak betah berada di rumah / ruangan, gelisah / cemas, bosan, marah, lebih emosional dan cepat kelelahan. Gejala lainnya yang tidak dominan yaitu frustasi, gugup, kesepian, kesulitan konsentrasi dan sulit melakukan aktivitas sehari-hari. Fenomena ini bukanlah sebuah penyakit, maka dilakukan pendekatan gejala dari International Classification of Diseases-10 (ICD-10) untuk memudahkan identifikasi dan analisis artikel. Hasilnya, cabin fever memiliki kemiripan penyebab dan gejala dengan Post-traumatic Stress Disorder (PTSD), Adjustment Disorders dan Claustrophobia. ${ }^{11}$ Sebelumnya, sudah ada sebuah rapid review dari Brooks et al. yang melaporkan gangguan psikologis mirip cabin fever dengan stressor dari durasi karantina, takut terinfeksi dan sulit memenuhi kebutuhan sehari-hari. ${ }^{12}$ Penelitian Jeong et al. juga mengungkapkan temuan gejala kecemasan $(7,6 \%)$, dan perasaan marah $(16,6 \%)$ pada masyarakat Korea saat menjalankan pembatasan sosial selama penyebaran MERS. ${ }^{6}$ Tuntutan berubahnya gaya hidup dan perilaku masyarakat akibat penyebaran virus menular memaksa berbagai rencana dibatalkan, pekerjaan bahkan kegiatan akademik terganggu dan hal ini dialami oleh seluruh lapisan masyarakat.

Perubahan negatif psikologis pada masyarakat dalam jumlah yang sangat besar selama pembatasan sosial merupakan topik yang menarik dalam bidang Epidemiologi Kesehatan Jiwa. Pembatasan sosial tidak dapat dihindari karena perannya sebagai tombak utama dalam memerangi penyebaran penyakit menular, namun tidak dapat mengenyampingkan juga fakta bahwa pelaksanaannya dalam waktu yang lama rentan mengganggu kesehatan mental masyarakat. Cabin fever sudah menjadi isu yang diangkat media nasional maupun internasional terutama selama pandemik Covid-19. Sudah ada penelitian kuantitatif dan kualitatif mengenai dampak psikologis akibat pelaksanaan pembatasan sosial saat penyebaran SARS, MERS maupun Covid-19 namun belum ditemukan tulisan ilmiah yang mengaitkannya dengan cabin fever. Oleh sebab itu, perlu dilakukan peninjauan literatur secara sistematis agar dapat menggambarkan kejadian cabin fever selama pembatasan soisal dan 
menjelaskannya menurut karakteristik populasi beserta faktor penyebabnya.

\section{Metode}

Mixed Method Systematic Review (MMSR) dengan convergent segregated approach dipilih karena penelitian ini melakukan analisis pada studi kualitatif, kuantitatif dan campuran untuk melakukan sintesis naratif dari dua dimensi temuan berbeda yaitu karakteristik populasi yang mengalami cabin fever dan faktor penyebab cabin fever. Proses pengumpulan data sampai terinklusi menggunakan diagram alur PRISMA (Preferred Reporting Items for Systematic Review and Meta-Analysis). ${ }^{13}$ Langkahnya diadaptasi dari tahapan MMSR di JBI Manual for Evidence Synthesis 2020 yaitu: ${ }^{14}$

\section{Idenfikasi Pertanyaan Penelitian}

Mengumpulkan fakta dan data yang ada, serta merumuskan masalahnya dan membuat pertanyaan penelitian yang bertujuan menggambarkan fenomena cabin fever selama pembatasan sosial saat pandemik $\mathrm{HCoV}$.

\section{Menentukan Kriteria Inklusi}

Kriteria inklusi artikel dibuat dengan pendekatan PICo (Population, Phenomena of Interest, Context, Type of studies). Populasinya masyarakat dari berbagai kalangan dan profesi yang terdampak pandemik SARS, MERS dan Covid-19; Fenomenanya mobilitas / aktivitas terbatas maupun kurungan / terpeangkan secara fisik atau psikis; Konteksnya dampak psikologis seperti gejala cabin fever; Studinya kualitatif, kuantitatif dan campuran. Kriteria yang terbentuk mengatur bahasa artikel, rentang publikasi, bentuk dan jenis artikel, usia responden serta substansi hasil penelitian yang dapat terinklusi.

\section{Strategi Pencarian Data}

Membuat kata kunci yang ditentukan melalui MeSH (Medical Subject Headings). Identifikasi dilakukan pada literatur yang dipublikasi sejak Januari 2004 sampai September 2020 dari ScienceDirect, PubMed, MEDLINE serta grey literature di Google Scholar dan ProQuest,. Hasil pencarian disimpan di Mendeley atau disaring langsung di database bila memungkinkan.

\section{Pemilihan Data dan Penilaian Artikel}

Flowchart PRISMA digunakan sebagai alur penyaringan artikel. ${ }^{13}$ Setelah proses identifikasi dilakukan screening untuk melihat kesesuaian judul, abstrak dan kelengkapan artikel. Peninjauan lebih dalam dilakukan pada tahap eligibility dengan melibatkan kriteria inklusi. Setelah terinklusi, quality appraisal dilakukan dengan check list pengembangan Audete et $a l$, yang menggunakan kriteria Walace et $a l$., dan sistem peringkat yang dimodifikasi Ohly et al. ${ }^{15-17}$ Setiap tahapan dan proses harus terdokumentasi dengan baik.

\section{Mengekstraksi Data}

Artikel diekstraksi dalam bentuk tabel menggunakan Microsoft Excel yang terdiri dari rincian populasi, paparan, hasil atau temuan penting beserta kualitas artikelnya.

6. Sintesis dan Integrasi Data

Hasil dipetakan menurut karakteristik responden, faktor penyebab dan gejala cabin fever yang timbul. Bukti studi kuantitatif, kualitatif dan campuran dijadikan sintesis naratif dan dapat diintegrasikan dengan analisis konfiguratif jika memungkinkan.

\section{Hasil}

Gambar 1 menunjukkan proses seleksi artikel dari identification sampai included. Pada tahap identification menghasilkan 1.081 buah artikel yang terdiri dari 226 di PubMed, 125 di Science Direct, 263 di MEDLINE, 250 di Google Scholar dan 217 di ProQuest. Sebanyak 605 buah tereliminasi berdasarkan relevansi judul, abstrak, bahasa dan duplikasi. Kemudian dilakukan proses screening yang mengeliminasi 536 artikel karena kondisijenis 
artikel dan tidak peer-reviewed. Dilakukan fulltext assessment pada 144 artikel yang semakin mengerucut pada kejadian cabin fever dan menyebabkan 86 buah tereliminasi. Tahap berikutnya yaitu eligibility dimana semua artikel sudah memiliki kesamaan latar belakang dan tujuan penelitian. Dari 58 artikel, hanya 11 artikel yang berhasil sampai tahap included.

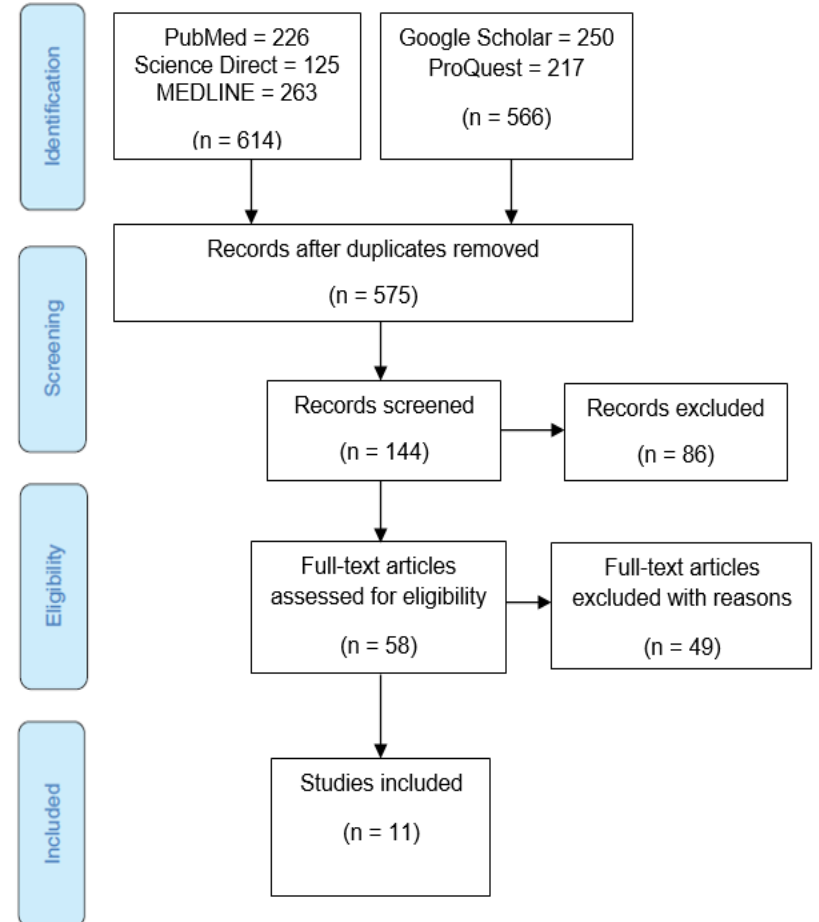

Gambar 1. Diagram Alur PRISMA

Tabel 1 menjelaskan bahwa artikel berasal dari 8 negara berbeda dengan 4 artikel terkait SARS (tahun 2003, 2004 dan 2007), 2 terkait MERS (tahun 2018 dan 2020) serta 5 terkait Covid-19 (tahun 2020). Sebagian besar menggunakan studi kuantitatif dengan metode cross-sectional. Artikel terkait SARS hanya berasal dari Toronto karena wilayah itu merupakan wilayah kasus tertinggi di Kanada dengan penyebaran yang cepat. Artikel terkait dampak psikologis selama MERS paling sulit ditemukan bahkan di PubMed dan ProQuest tidak ada sama sekali. Sedangkan artikel Covid-19 memiliki responden penelitian dan asal negara yang paling beragam. Dari 9 artikel kuantitatif, 7 berkualitas "sedang" dan 2 berkualitas "kuat". Seluruh artikel kualitatif berkualitas "kuat" (2 buah). Penelitian dari Maunder et al. satu-satunya yang berkualitas "kuat" dan memberikan informasi terbanyak pada pemetaan. Hasil penelitian setiap artikel dijabarkan menurut tema karakteristik populasi, faktor penyebab dan gejala cabin fever yang muncul.

\section{Pembahasan}

1. Cabin Fever Menurut Karakteristik Populasi

a) Jenis Kelamin

Perempuan lebih rentan dan berisiko mengalami tekanan psikis seperti stres, depresi, tingkat kekhawatiran dan ketakutan yang tinggi karena perempuan memiliki Intolerance Uncertainity yang lebih rendah. ${ }^{18,19}$ Pembatasan sosial selama penularan virus terjadi menimbulkan ketidakpastian dari berbagai hal (pekerjaan, akdemik, keamanan, kesehatan dan ekonomi) namun tingkat toleransi setiap orang berbeda dalam menghadapinya.

b) Usia

Kelompok usia 18-49 tahun berisiko tinggi mengalami gejala PTSD dan depresi. Penularan penyakit ini memberikan tekanan yang tinggi pada kelompok usia produktif karena selain mereka berisiko tinggi terinfeksi, mereka juga paling berperan dalam upaya pengendalian penyakit. Sedangkan, pada kelompok usia lebih dari 50 tahun rentan mengalami kecemasan, depresi, insomnia dan kesepian akibat penularan penyakit yang diperparah dengan pembatasan sosial. ${ }^{19-21}$

c) Pekerjaan

Tenaga kesehatan yang merawat pasien MERS dan Covid-19 memiliki gejala PTSD bahkan 40,3\% diantaranya memenuhi syarat diagnosis PTSD. ${ }^{21,22}$ Saat tenaga kesehatan menangani SARS, gejala yang timbul paling mirip dengan cabin fever yaitu mengalami gejala PTSD, perasaan terkurung, frustasi khawatir, marah, cepat lelah dan merasa kesepian selama beberapa minggu. ${ }^{23}$ Pekerja rumah sakit non-medis juga mengalami tekanan yang sama beratnya karena banyaknya beban pelayanan. 
Tabel 1. Ekstraksi Artikel Terinklusi

\begin{tabular}{|c|c|c|c|c|c|c|}
\hline \multirow{2}{*}{ No } & \multirow{2}{*}{$\begin{array}{c}\text { Penulis, Tahun, } \\
\text { Negara, Judul }\end{array}$} & \multirow{2}{*}{ Desain } & \multicolumn{2}{|c|}{ Tema } & \multirow[t]{2}{*}{$\begin{array}{c}\text { Gejala CF } \\
\text { yang Timbul }\end{array}$} & \multirow[t]{2}{*}{ Kualitas } \\
\hline & & & $\begin{array}{l}\text { Karakterist } \\
\text { ik populasi }\end{array}$ & $\begin{array}{c}\text { Faktor } \\
\text { Penyebab }\end{array}$ & & \\
\hline 1. & $\begin{array}{l}\text { (Al-Rabiaah et.al, } \\
\text { 2020, Arab Saudi) } \\
\text { MERS-CoV } \\
\text { associated stress } \\
\text { among medical } \\
\text { students at a } \\
\text { university teaching } \\
\text { hospital in Saudi } \\
\text { Arabia }\end{array}$ & $\begin{array}{l}\text { Kuantitatif } \\
\text { (Cross- } \\
\text { sectional) }\end{array}$ & 1. Mahasiswa & $\begin{array}{l}\text { 1. Social } \\
\text { distancing } \\
\text { 2. Melakukan } \\
\text { protokol } \\
\text { kesehatan }\end{array}$ & $\begin{array}{l}\text { Stres, Gejala } \\
\text { PTSD, Depresi }\end{array}$ & Sedang \\
\hline 2. & $\begin{array}{l}\text { (Chen et al., 2020, } \\
\text { Cina) }{ }^{24} \\
\text { Quarantine experience } \\
\text { of close contacts of } \\
\text { COVID-19 patients in } \\
\text { China: A qualitative } \\
\text { descriptive study }\end{array}$ & Kualitatif & $\begin{array}{l}\text { 1. Pasien } \\
\text { kontak erat } \\
\text { Covid-19 }\end{array}$ & $\begin{array}{l}\text { 1. Karantina } \\
\text { 2. Pengetahuan } \\
\text { karantina } \\
\text { rendah }\end{array}$ & $\begin{array}{l}\text { Takut, Gugup, } \\
\text { Mirip } \\
\text { clausthrophobia, } \\
\text { Tidak sabar, } \\
\text { Kesal, Kesepian }\end{array}$ & Kuat \\
\hline 3. & $\begin{array}{l}\text { (Forte et al., } 2020 \text {, } \\
\text { Italia })^{20} \text { The Enemy } \\
\text { Which Sealed the } \\
\text { World: Effects of } \\
\text { COVID-19 Diffusion } \\
\text { on the Psychological } \\
\text { State of the Italian } \\
\text { Population }\end{array}$ & $\begin{array}{l}\text { Kuantitatif } \\
\text { (Cross- } \\
\text { sectional) }\end{array}$ & $\begin{array}{l}\text { 1. Usia >50 } \\
\text { tahun } \\
\text { 2. Usia 18-49 } \\
\text { tahun } \\
\text { 3. Pasien } \\
\text { kontak erat } \\
\text { Covid-19 }\end{array}$ & $\begin{array}{l}\text { 1. Social } \\
\text { distancing } \\
\text { 2. Mengetahui } \\
\text { kerabat positif } \\
\text { / meninggal } \\
\text { akibat Covid- } \\
19\end{array}$ & $\begin{array}{l}\text { Kecemasan, } \\
\text { Risiko tinggi } \\
\text { PTSD, Gejala } \\
\text { PTSD, } \\
\text { Perubahaan } \\
\text { negatif }\end{array}$ & Sedang \\
\hline 4. & $\begin{array}{l}\text { (Hawryluck et al., } \\
2004, \text { Kanada) } \\
\text { SARS Control and } \\
\text { Psychological Effects } \\
\text { of Quarantine, } \\
\text { Toronto, Canada }\end{array}$ & $\begin{array}{l}\text { Kuantitatif } \\
\text { (Cross- } \\
\text { sectional) }\end{array}$ & $\begin{array}{l}\text { 1. Tenaga } \\
\text { kesehatan } \\
\text { 2. Non-tenaga } \\
\text { kesehatan } \\
\text { 3. Usia 26-45 } \\
\text { tahun }\end{array}$ & $\begin{array}{l}\text { 1. Durasi } \\
\text { karantina >10 } \\
\text { hari } \\
\text { 2. Melakukan } \\
\text { protokol } \\
\text { kesehatan } \\
\text { 3. Informasi } \\
\text { tentang } \\
\text { karantinaa } \\
\text { terbatas } \\
\text { 4. Mengenal } \\
\text { orang positif } \\
\text { SARS } \\
\text { 5. Pendapatan } \\
\text { rumah tangga } \\
\text { rendah }\end{array}$ & $\begin{array}{l}\text { Gejala PTSD, } \\
\text { Depresi, Stres, } \\
\text { Marah }\end{array}$ & Sedang \\
\hline 5 & $\begin{array}{l}\text { (Landis, 2003, } \\
\text { Kanada) } \\
\text { The Impact of the } \\
2003 \text { SARS Outbreak } \\
\text { on Medical Students } \\
\text { at the University of } \\
\text { Toronto }\end{array}$ & $\begin{array}{l}\text { Kuantitatif } \\
\text { (Cross- } \\
\text { sectional) }\end{array}$ & 1. Mahasiswa & $\begin{array}{l}\text { 1. Karantina } \\
\text { 2. Mengenal } \\
\text { orang positif } \\
\text { SARS }\end{array}$ & $\begin{array}{l}\text { Merasa } \\
\text { terisolasi, Takut } \\
\text { tertular, Sulit } \\
\text { konsentrasi }\end{array}$ & Kuat \\
\hline 6 & $\begin{array}{l}\text { (Lee et al., 2018, } \\
\text { Korea) } \\
\text { Psychological impact } \\
\text { ofthe } 2015 \text { MERS } \\
\text { outbreak on hospital } \\
\text { workers and } \\
\text { quarantined }\end{array}$ & $\begin{array}{l}\text { Mixed } \\
\text { methods4 }\end{array}$ & $\begin{array}{l}\text { 1. Tenaga } \\
\text { kesehatan } \\
\text { 2. Pasien } \\
\text { MERS } \\
\text { 3. Usia 30-an } \\
\text { tahun } \\
\text { 4. Usia 3-70 }\end{array}$ & 1. Karantina & $\begin{array}{l}\text { Risiko tinggi } \\
\text { PTSD, Rentan } \\
\text { kecemasan dan } \\
\text { depresi, Gejala } \\
\text { PTSD, Positif } \\
\text { PTSD, Gejala } \\
\text { kecemasan, }\end{array}$ & Sedang \\
\hline
\end{tabular}




\begin{tabular}{|c|c|c|c|c|c|c|}
\hline & hemodialysis patients & & tahun & & Depresi & \\
\hline 7 & $\begin{array}{l}\text { (Maunder et al., 2003, } \\
\text { Kanada) } \\
\text { The immediate } \\
\text { psychological and } \\
\text { occupational impact } \\
\text { of the } 2003 \text { SARS } \\
\text { outbreak in a teaching } \\
\text { hospital }\end{array}$ & Kualitatif & $\begin{array}{l}\text { 1. Pasien SARS } \\
\text { 2. Pasien non- } \\
\text { SARS } \\
\text { 3. Tenaga } \\
\text { kesehatan }\end{array}$ & $\begin{array}{l}\text { 1. Social } \\
\text { distancing } \\
\text { 2. Membaca / } \\
\text { menonton } \\
\text { berita secara } \\
\text { intens } \\
\text { 3. Stigma dan } \\
\text { ketidakpastian } \\
\text { 4. Merawat } \\
\text { rekan kerja }\end{array}$ & $\begin{array}{l}\text { Marah, } \\
\text { Khawatir, Lebih } \\
\text { emosional, } \\
\text { Frustasi, Bosan, } \\
\text { Kesepian, } \\
\text { Gelisah, } \\
\text { Kecemasan, } \\
\text { Cepat lelah, } \\
\text { Mudah } \\
\text { tersinggung }\end{array}$ & Kuat \\
\hline 8 & $\begin{array}{l}\text { (Parlapani et al., } \\
\text { 2020, Yunani) } \\
\text { Intolerance of } \\
\text { Uncertainty and } \\
\text { Loneliness in Older } \\
\text { Adults During the } \\
\text { COVID-19 Pandemic }\end{array}$ & $\begin{array}{l}\text { Kuantitatif } \\
\text { (Cross- } \\
\text { sectional) }\end{array}$ & $\begin{array}{l}\text { 1. Usia }>60 \\
\text { tahun }\end{array}$ & $\begin{array}{l}\text { 1. Tinggal } \\
\text { sendirian }\end{array}$ & $\begin{array}{l}\text { Kecemasan, } \\
\text { Depressi, } \\
\text { Kesepian, Takut }\end{array}$ & Sedang \\
\hline 9 & $\begin{array}{l}\text { (Reynolds et al., } \\
2020, \text { Kanada) } \\
\text { Understanding, }^{26} \\
\text { compliance and } \\
\text { psychological impact } \\
\text { of the SARS } \\
\text { quarantine experience }\end{array}$ & $\begin{array}{l}\text { Kuantitatif } \\
\text { (Cross- } \\
\text { sectional) }\end{array}$ & $\begin{array}{l}\text { 1. Tenaga } \\
\text { kesehatan } \\
\text { 2. Non-tenaga } \\
\text { kesehatan }\end{array}$ & 1. Karantina & $\begin{array}{l}\text { Gejala PTSD, } \\
\text { bosan, } \\
\text { terkurung, } \\
\text { frustasi, } \\
\text { kesepian, marah }\end{array}$ & Kuat \\
\hline 10 & $\begin{array}{l}\text { (Senisik et al., 2020, } \\
\text { Turki) } \\
\text { The effect of isolation } \\
\text { on athletes' mental } \\
\text { health during the } \\
\text { COVID-19 pandemic }\end{array}$ & $\begin{array}{l}\text { Kuantitatif } \\
\text { (Cross- } \\
\text { sectional) }\end{array}$ & $\begin{array}{l}\text { 3. Atlit beregu } \\
\text { putra dan } \\
\text { putri } \\
\text { 4. Atlit individu } \\
\text { putra dan } \\
\text { putri } \\
\text { 5. Non-atlit }\end{array}$ & 2. Karantina & $\begin{array}{l}\text { Depresi, } \\
\text { kecemasan, } \\
\text { PTSD }\end{array}$ & Sedang \\
\hline 11 & $\begin{array}{l}\text { (Tull et al., 2020, } \\
\text { Amerika) } \\
\text { Psychological } \\
\text { Outcomes Associated } \\
\text { with Stay-at-Home } \\
\text { Orders and the } \\
\text { Perceived Impact of } \\
\text { COVID-19 on Daily } \\
\text { Life }\end{array}$ & $\begin{array}{l}\text { Kuantitatif } \\
\text { (Cross- } \\
\text { sectional) }\end{array}$ & $\begin{array}{l}\text { 1. Usia 20-74 } \\
\text { tahun } \\
\text { 2. Ras } \\
\text { 3. Memiliki } \\
\text { Anak }\end{array}$ & $\begin{array}{l}\text { 1. Karantina } \\
\text { 2. Tinggal } \\
\text { sendirian } \\
\text { 3. Tinggal } \\
\text { dengan } \\
\text { kerabat }\end{array}$ & $\begin{array}{l}\text { Kecemasan, } \\
\text { Kesepian, } \\
\text { Khawatir } \\
\text { finansial }\end{array}$ & Sedang \\
\hline
\end{tabular}

Pada kelompok mahasiswa, saat terjadi MERS cenderung lebih mudah stres. Saat terjadi SARS, stres bahkan diperparah dengan sulitnya berkonsentrasi. Lalu, pada pandemik Covid-19 dampak psikologis yang negatif semakin kompleks yaitu menjadi depresi, kecemasan tinggi, merasa lebih tertekan sampai sulit melakukan aktivitas sehari-hari, selalu merasa lelah dan kesal akibat berbagai upaya pembatasan sosial. ${ }^{18,20,25,29}$

Atlit juga mengalami masa sulit selama pembatasan sosial karena menjalankan masa hiatus yang tidak terprediksi durasinya. Senisik et al. melaporkan gejala PTSD ditemukan pada seluruh atlit namun lebih rendah pada kelompok atlit beregu putra dibandingkan atlit beregu putri serta atlit individu putra dan putri. ${ }^{27}$ Rutin melakukan aktifitas fisik selama pembatasan sosial mampu mengurangi gejala PTSD, depresi dan kecemasan.

d) Pasien

Pasien SARS, MERS dan kontak erat Covid-19 mengalami rasa bersalah karena tertular, takut akan kesejahteraan keluarganya, mudah marah, gugup dan mengalami gejala claustrophobia. ${ }^{20,23,24}$ 
Pasien penyakit lainnya frustasi karena tidak diizinkan pulang. Pasien yang berniat melakukan karantina dan pengobatan di rumah sakit sejak awal memiliki tingkat kecemasan dan depresi yang lebih rendah. ${ }^{21}$

\section{Faktor Penyebab Cabin Fever}

a) Penyebab Langsung

Melaksanakan social distancing jangka panjang membuat masyarakat mengalami depresi, sulit melakukan aktivitas harian dan selalu merasa lelah. ${ }^{20}$ Pasien di rumah sakit yang juga tetap harus melakukan social distancing merasakan kesepian dan bosan. ${ }^{23}$ Melaksanakan karantina setidaknya lebih dari 7 hari dilaporkan paling mirip dengan cabin fever yaitu gejala claustrophobia, kesepian, marah, bosan, demotivasi, sulit konsentrasi, merasa terisolasi serta timbul gejala PTSD, kecemasan dan depresi. Melakukan karantina dirumah lebih berisiko mengalami PTSD dan gejala claustrophobia. $^{21,25,27,28}$

Masyarakat yang tinggal sendirian selama pembatasan sosial mengalami kecemasan finansial, kesepian, dan depresi. ${ }^{19,28}$ Laporan Hawryluck et al. menyatakan orang dengan status menikah atau memiliki anak belum tentu terhindar dari risiko PTSD. Durasi karantinalah yang lebih berpengaruh meningkatkan gejala PTSD (>10 hari). ${ }^{7}$

Salah satu aktivitas rumah sakit yang juga menjadi penyebab langsung cabin fever yaitu merawat rekan kerja, yang mana juga seturut dengan penelitian Rosenblatt et al. ${ }^{10,23}$ Gejala yang timbul yaitu cepat lelah, mudah tersinggung, lebih emosional dan takut tertular namun tetap tertekan karena harus merawat orang yang terinfeksi disaat dirinya juga sedang berjuang melawan virus.

b) Penyebab Tidak Langsung

Selama pembatasan sosial masyarakat menyesuaikan diri dengan menghindari kerumunan dan meningkatkan perilaku lebih higenis, namun Al-rabiaah et al. melaporkan bahwa perilaku tersebut meningkatkan stres. ${ }^{18}$ Bahkan, secara statistik dilaporkan penggunaan masker seharian menimbulkan gejala PTSD $(\mathrm{p}=0.002)^{7}$, padahal penggunaan masker yang dikombinasikan dengan social distancing efektif meratakan kurva epidemiologi penyebaran virus. ${ }^{30}$

Selama pembatasan sosial masyarakat memiliki lebih banyak waktu untuk menerima informasi dan punya rasa ingin tahu yang tinggi. Informasi yang tepat waktu dan akurat sangat penting saat terjadi penyebaran penyakit menular, namun Maunder et al. melaporkan membaca / menonton berita secara intens justru meningkatkan kegelisahan dan kecemasan. ${ }^{23}$ Akses terhadap informasi yang terbatas dan pengetahuan yang rendah tentang pembatasan sosial menimbulkan rasa takut, gugup dan marah di masyarakat. 7,23,24

Berikutnya yaitu contact tracing yang merupakan prosedur wajib untuk menelusuri sumber dan penyebaran kasus, namun hal ini ternyata dilaporkan dapat menimbulkan kecemasan dan gejala claustrophobia. ${ }^{23}$ Kegiatan ini juga membuat pasien mencemaskan orang yang ditelusuri berpotensi mengalami stigmatisasi bahkan dapat kehilangan pekerjaannya. $^{12}$ Pendapatan gabungan rumah tangga yang menurun selama pandemi menimbulkan gejala PTSD dan depresi. ${ }^{7}$ Bukan hanya orang yang ditelusuri saat contact tracing yang dapat mengalami stigmatisasi, hal ini justru sangat melekat pada pasien yang baru saja sembuh dari SARS, MERS dan Covid-19 sehingga mereka lebih mudah gelisah dan takut menularkan. Masyarakat masih banyak yang percaya bahwa mereka tetap bisa menularkan walau telah dinyatakan sembuh.

Penyebab tidak langsung lainnya yang dapat menimbulkan cabin fever yaitu mengetahui kerabat positif / meninggal setelah terinfeksi yang 
menyebabkan timbul perasaan cepat lelah, khawatir, gugup dan menjadi lebih emosional. ${ }^{7,25}$ Hal ini wajar terjadi karena masyarakat memahami protokol kesehatan yang ketat saat menangani pasien dan menangani jenazah yang terinfeksi. Segalanya terbayang menjadi jauh lebih sulit dan terbatas jika terinfeksi, bahkan bagi keluarga yang merawat dan harus mengurus berbagai administrasi.

\section{Kesimpulan}

Populasi yang rentan mengalami cabin fever yaitu wanita, semua usia dan tenaga kesehatan yang berhubungan langsung dengan pasien positif. Atlit beregu putra dan pasien yang sejak awal sudah berniat karantina dengan kebutuhan pengobatan khusus berpeluang terhindar dari cabin fever. Faktor yang paling berisiko menyebabkan cabin fever secara langsung yaitu social distancing, lockdown, karantina dan merawat rekan kerja. Contact tracing dan melakukan test berkali-kali, serta mengenal orang yang terinfeksi menjadi faktor penyebab tidak langsung yang paling berisiko menimbulkan cabin fever.

Atas temuan tersebut maka disarankan pada pihak pemangku kebijakan kesehatan untuk memperhatikan isu psikologis selama pembatasan sosial dengan membuat program atau layanan konseling yang dapat mencegah cabin fever. Kolaborasi dengan universitas dan lembaga lainnya juga diperlukan untuk aktif mempublikasikan informasi terkait penyakit dan penanganannya. Peneliti berikutnya diharapkan dapat menggali lebih lanjut kejadian cabin fever selama pandemi Covid-19 beserta cara menanganinya.

\section{Ucapan Terimakasih}

Terima kasih diucapkan kepada semua pihak yang telah membantu dalam penelitian ini dan kepada JEKK karena telah mengizinkan untuk menggunakan template yang telah ditetapkan.

\section{Daftar Pustaka}

1. Afshar Z, Ebrahimpour S, Javanian M, Koppolu V, Vasigala VR, Hasanpour A, et al. 2020. Coronavirus Disease 2019 (COVID-19), MERS and SARS: Similarity and Difference. $J$ Acute Dis.9(5):194-9.

2. World Health Organization. Coronavirus Disease (COVID-19) Weekly Epidemiological Updated 27 December 2020. 2020;1-17.

3. World Health Organization. MERS Situation Update January 2020. 2020.

4. World Health Organization. Update 95 SARS : Chronology of a serial killer. 2003.

5. Jefferson $\mathrm{T}$, Del Mar CB, Dooley L, Ferroni E, Al-Ansary LA, Bawazeer GA, et al. 2011. Physical interventions to interrupt or reduce the spread of respiratory viruses. Cochrane database Syst Rev. (7).

6. Jeong H, Yim HW, Song YJ, Ki M, Min JA, Cho J, et al. 2016. Mental health status of people isolated due to Middle East Respiratory Syndrome. Epidemiol Health. 38:1-7.

7. Hawryluck L, Gold WL, Robinson S, Pogorski S, Galea S, Styra R. 2004. SARS control and psychological effects of quarantine, Toronto, Canada. Emerg Infect Dis. 10(7):1206-12.

8. Petrosillo N, Viceconte G, Ergonul O, Ippolito G, Petersen E. 2020. COVID-19, SARS and MERS: are they closely related? Clin Microbiol Infect. 26:72934.

9. Liu Y, Gayle AA, Wilder-Smith A, Rocklöv J. 2020. The Reproductive 
Number of COVID-19 is Higher Compared to SARS Coronavirus. J Travel Med. 27(2):1-4.

10. Rosenblatt PC, Anderson RM, Johnson PA. 1984. The meaning of "cabin fever." J Soc Psychol. 123(1):43-53.

11. World Health Organization. The ICD-10 Classification of Mental and Behavioural Disorders: Clinical description and diagnostic guidelines. 10th ed. Vol. 2. World Health Organization; 1993.

12. Brooks SK, Webster RK, Smith LE, Woodland L, Wessely S, Greenberg N, et al. 2020. The psychological impact of quarantine and how to reduce it: rapid review of the evidence. Lancet. 1-9.

13. Moher D, Liberati A, Tetzlaff J, Altman DG. 2009. Preferred reporting items for systematic reviews and meta-analyses: The PRISMA statement. BMJ. 339(7716):332-6.

14. Aromataris E, Munn Z, editors. JBI Manual for Evidence Synthesis. JBI; 2020.

15. Audate PP, Fernandez MA, Cloutier G, Lebel A. 2019. Scoping review of the impacts of urban agriculture on the determinants of health. BMC Public Health. 19(1):1-14.

16. Wallace A, Croucher K, Quilgars D, Baldwin S. 2004. Meeting the challenge: Developing systematic reviewing in social policy. Policy Polit. 32(4):455-70.

17. Ohly H, Gentry S, Wigglesworth R, Bethel A, Lovell R, Garside R. 2016. A systematic review of the health and wellbeing impacts of school gardening: Synthesis of quantitative and qualitative evidence. BMC Public Health. 16(286):1-36.
18. Al-rabiaah A, Temsah M, Al-eyadhy AA. 2020. Middle East Respiratory Syndrome-Corona Virus (MERS-CoV) associated stress among medical students at a university teaching hospital in Saudi Arabia. J Infect Public Health. 13.

19. Parlapani E, Holeva V, Nikopoulou VA, Sereslis K, Athanasiadou M, Godosidis A, et al. 2020. Intolerance of Uncertainty and Loneliness in Older Adults During the COVID-19 Pandemic. Front Psychiatry. 11:1-12.

20. Forte G, Favieri F, Tambelli R, Casagrande M. 2020. The Enemy Which Sealed the World: Effects of COVID-19 Diffusion on the Psychological State of the Italian Population. J Clin Med. 9(6):1802.

21. Lee SM, Sub Kang W, Cho A-R, Kim T, Park JK. 2018. Psychological impact of 2015 MERS outbreak on hospital workers and quarantined hemodialysis patients. Compr Psychiatry. 87:123-7.

22. Si M, Su X, Jiang Y, Wang W, Gu X, Ma L, et al. 2020. Psychological Impact of COVID-19 on Medical Care Workers in China. Infect Dis Poverty. 9(113):1-13.

23. Maunder R, Hunter J, Vincent L, Bennett J, Peladeau N, Leszcz M, et al. 2003. The immediate psychological and occupational impact of the 2003 SARS outbreak in a teaching hospital. Cmaj. 168(10):1245-51.

24. Chen D, Song F, Tang L, Zhang H, Shao J, Qiu R, et al. 2020. Quarantine experience of close contacts of COVID19 patients in China: A qualitative descriptive study Dandan. Gen Hosp Psychiatry. 66:81-8.

25. Landis MS, Bradley JW, Chan L, Ahmad Y, Klevan AE, Zahirieh A, et al. 2005. 
The Impact of the 2003 SARS Outbreak on Medical Students at the University of Toronto. Univ Toronto Med J. 82(3):158-64.

26. Reynolds DL, Garay JR, Deamond SL, Moran MK, Gold W, Styra R. 2007. Understanding, compliance and psychological impact of the SARS quarantine experience. Epidemiol Infect. 136:997-1007.

27. Şenışık S, Denerel N, Köyağasığlu $\mathrm{O}$, Tunç S. 2020. The effect of isolation on athletes' mental health during the COVID-19 pandemic. Phys Sportsmed. $1-7$.

28. Tull MT, Edmonds KA, Scamaldo KM, Richmond JR, Rose JP, Gratz KL. 2020. Psychological Outcomes Associated with Stay-at-Home Orders and the Perceived Impact of COVID-19 on Daily Life. Psychiatry Res. 289:1-6.

29. Cao W, Fang Z, Hou G, Han M, Xu X, Dong J, et al. 2020. The psychological impact of the COVID-19 epidemic on college students in China. Psychiatry Res. 287:1-5.

30. Li T, Liu Y, Li M, Qian X, Dai SY. 2020. Mask or no mask for COVID-19: A public health and market study. PLoS One. 15(8):1-17. 